Research Paper

\title{
Natural Isotopic Composition of Particulate Organic Nitrogen in the Eastern and Central Arabian Sea
}

\author{
NAVEEN GANDHI ${ }^{1,2, *}$ and R RAMESH ${ }^{1}$ \\ ${ }^{1}$ Geosciences Division, Physical Research Laboratory, Navrangpura, Ahmedabad 380 009, India \\ ${ }^{2}$ Present address: Centre for Climate Change Research, Indian Institute of Tropical Meteorology, \\ Dr. Homi Bhabha Road, Pashan, Pune 411 008, India
}

(Received on 01 June 2015; Revised on 03 May 2016; Accepted on 12 May 2016)

\begin{abstract}
We report measurements of isotopic composition of nitrogen $\left(\delta^{15} \mathrm{~N}\right)$ of particulate organic nitrogen (PON) at eighteen sampling locations in the north-eastern and central Arabian Sea during the waning phase of the summer monsoon. This season is ideal to detect signatures of upwelling and denitrification in the Arabian Sea. Our observations indicate significant spatial variability in the $\delta^{15} \mathrm{~N}$ as a result of the upper ocean response to the monsoonal forcing that triggers upwelling and thus supplies sub surface nitrate to the surface. An increasing (decreasing) trend has been found in the $\delta^{15} \mathrm{~N}$ (PON) from the upwelling zone to the open ocean, which tracks the progressive utilization of advected nitrate from the coast. Monsoondriven mixing and supply of nitrate and/or PON with lower $\delta^{15} \mathrm{~N}$ from the west through advection are mainly confined to the upper $50 \mathrm{~m}$, however, at some locations advection imprints its signature in the deeper layers as well. The results have implications to the interpretation of sedimentary $\delta^{15} \mathrm{~N}$ record from this region and deciphering the role of monsoonal forcing over the nitrogen utilization by plankton.
\end{abstract}

\section{Introduction}

Nitrogen isotopic composition $\left(\delta^{15} \mathrm{~N}\right.$, expressed as deviation in parts per thousand (\%o) from atmospheric air standard) of particulate organic nitrogen (PON) provides an insight into various biogeochemical transformations occurring in the marine nitrogen cycle (e.g., Gandhi et al., 2011a). The $\delta^{15} \mathrm{~N}$ of phytoplankton varies as a result of biologically mediated isotopic discrimination and primarily depends on the $\delta^{15} \mathrm{~N}$ of the $\mathrm{N}$ source and the biological isotopic fractionation during uptake and assimilation of the nutrient source. Under a nitrogen replete environment, phytoplankton preferentially assimilate ${ }^{14} \mathrm{~N}$ relative to ${ }^{15} \mathrm{~N}$ resulting in the lower $\delta^{15} \mathrm{~N}$ of phytoplankton relative to that of the nitrogen source. On the other hand, under nitrogen limiting conditions, phytoplankton utilize available nitrogen completely and $\delta^{15} \mathrm{~N}$ of phytoplankton closely reflects that of the nitrogen source (Altabet and McCarthy, 1985). Cynobacteria lowers the $\delta^{15} \mathrm{~N}$ ( 0.6\%o; Emerson et al., 1991) of PON by converting atmospheric $\mathrm{N}_{2}\left(\delta^{15} \mathrm{~N} \mathrm{H}^{=} 0 \%\right.$ ) into organic nitrogen.
Further, nitrogen recycling also lowers the $\delta^{15} \mathrm{~N}$ of PON, because of isotopic fractionation during heterotrophic processes. The low- $\delta{ }^{15} \mathrm{~N}$ ammonium released by zooplankton is assimilated by phytoplankton leading to a lower $\delta^{15} \mathrm{~N}$ of surface PON (Altabet, 1988). Further, the $\delta^{15} \mathrm{~N}$ of PON also depends on phytoplankton species, physiology and the rate and phase of growth of phytoplankton (Montoya and MaCarthy, 1995). Sinking particulate matter likely to propagate these surface generated signals to the sea floor and thus, nitrogen isotopic compositions of sediments are being used to decipher the information on long-term variation in surface nitrogen utilization and critical oceanic $\mathrm{N}$ cycle processes (Altabet and Francois, 1994). In this context, measurements of the $\delta^{15} \mathrm{~N}$ of plankton and dissolved inorganic nitrogen are critical to the interpretation of sedimentary $\delta^{15} \mathrm{~N}$ records as well as in quantifying the sources of nitrogen that support production in contemporary oceanic ecosystems (Montoya, 2008).

A variety of geochemical and biological

*Author for Correspondence: E-mail: naveen@tropmet.res.in 
processes are known to be active in the Arabian Sea; e.g., higher primary productivity during the winter and summer monsoons due to the entrainment of nutrients into the mixed layer by convective overturning (Madhupratap et al., 1996; Gandhi et al., 2011b) and coastal upwelling (Barber et al., 2001), respectively. Such episodic events of higher productivity result in oxygen deficiency in middle layers of the water column (Naqvi, 1987). Loss of oxidized form of nitrogen to the atmosphere by intense denitrification and anaerobic ammonium oxidation is also observed (Bange et al., 2005; Nicholls et al., 2007). The Arabian Sea, with its well-developed oxygen minimum zone (OMZ) is one of the major regions of water column denitrification in the world ocean (Naqvi, 1987). However, the basin gains new nitrogen from the atmosphere by the occurrence of $\mathrm{N}_{2}$-fixing cynobacteria, mainly Trichodesmium bloom during inter-monsoon every year (Devassy et al., 1978; Gandhi et al., 2010; 2011a). All the above processes affect the $\delta^{15} \mathrm{~N}$ of the inorganic nitrogen pool and hence the average $\delta^{15} \mathrm{~N}$ of PON and sinking particles. Study of $\delta^{15} \mathrm{~N}$ of surface PON may elucidate the strength of certain water column processes.

Here, we discuss the vertical profiles of $\delta^{15} \mathrm{~N}$ of PON in the north-eastern and central Arabian Sea during the waning phase of the summer monsoon (June-September). Surface temperature, nutrients and chlorophyll data from the same cruise are presented elsewhere (Naqvi et al., 2010) and referred to for details.

\section{Methodology}

Sampling was performed along the cruise track shown in the Fig. 1 during 4-25 Sep 2004. Samples were collected for nitrogen isotopic composition of natural PON at eighteen Stations using Niskin bottles, mounted on a CTD rosette from various depths, mostly up to $\sim 100 \mathrm{~m}$, however, at two Stations (1 and 2) up to $1500 \mathrm{~m}$. Further, at four Stations (8-10, 13, and 15) Station depths were shallower, so samples were collected only up to $\sim 50 \mathrm{~m}$ depth. $2 \mathrm{~L}$ of sea water was collected from each depth. After collection, sample bottles were closed immediately to avoid any atmospheric contamination.Immediately after the collection, all samples were filtered through precombusted $\left(4 \mathrm{hrs}\right.$ at $\left.400^{\circ} \mathrm{C}\right) 47 \mathrm{~mm}$ diameters and $0.7 \mu \mathrm{m}$ pore size Whitman $\mathrm{GF} / \mathrm{F}$ filters. Care was

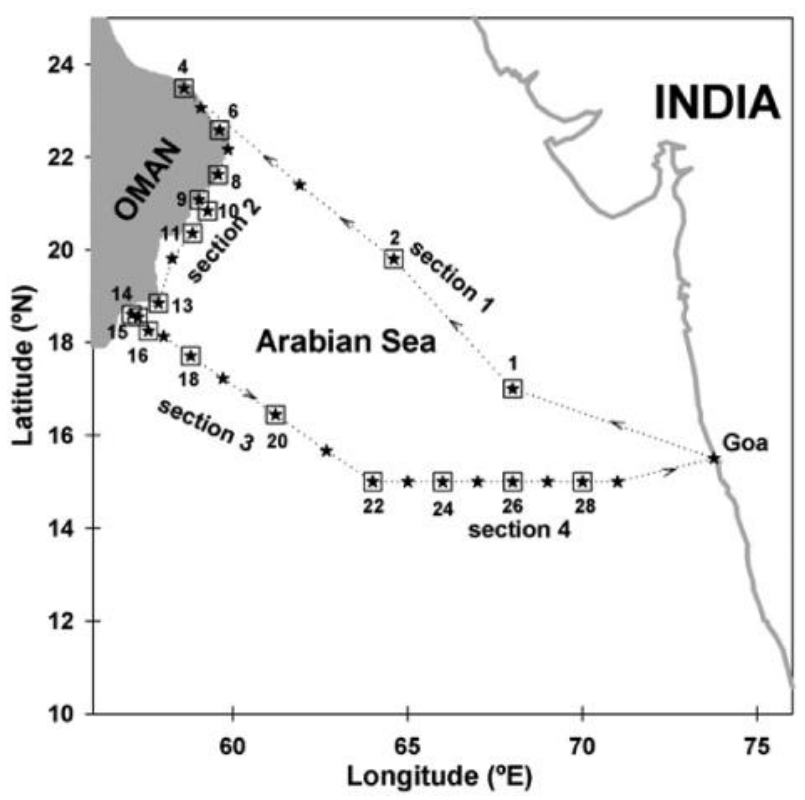

Fig. 1: Sampling locations (filled stars) in the central and western Arabian Sea during 4-25 Sep 2004. Samples were collected at eighteen Stations (rectangles) for measurement of PON and $\delta^{15} \mathrm{~N}$ of PON. Dotted line shows the cruise track and the direction shown with arrows. See the text for details about the four different Sections (1 to 4)

taken to minimize atmospheric contamination by opening sample bottles sequentially. After filtration, filters were dried in an oven at $50^{\circ} \mathrm{C}$ overnight and stored for further mass spectrometric analysis.

For the present study, a CarloErba elemental analyzer interfaced via Conflo III to a Finnigan Delta Plus mass spectrometer, whcih was used to measure PON and atom $\%{ }^{15} \mathrm{~N}$ in the samples. The technique for sub-microgram level ${ }^{15} \mathrm{~N}$ determination (Owens and Rees, 1989) was followed. Two standards USGS32 $\left(\mathrm{KNO}_{3}\right)$ and IAEA-N-2 $\left(\left[\mathrm{NH}_{4}\right]_{2} \mathrm{SO}_{4}, \# 342\right)$ were used to check the accuracy of the measurements. Precision for the $\delta^{15} \mathrm{~N}$ determination was $\pm 0.1 \%$. The average uncertainty associated with the determination of PON was less than $6 \% . \delta^{15} \mathrm{~N}$ is defined as:

$$
\delta^{15} \mathrm{~N}=\left(\frac{\mathrm{R}_{\text {sample }}}{\mathrm{R}_{\text {standard }}}-1\right) * 1000
$$

Where, $\mathrm{R}$ is the ratio of ${ }^{15} \mathrm{~N}$ to ${ }^{14} \mathrm{~N}$. All values of $\delta^{15} \mathrm{~N}$ presented are relative to the ${ }^{15} \mathrm{~N} /{ }^{14} \mathrm{~N}$ ratio of atmospheric $\mathrm{N}_{2}$. 
As mentioned earlier, $\delta^{15} \mathrm{~N}$ of PON at a particular location is a function of several processes such as remineralization, vertical mixing, and lateral advection; therefore the mean $\delta^{15} \mathrm{~N}$, weighted with PON was calculated to decouple and identify different processes. The weighted $\delta^{15} \mathrm{~N}$ of PON is then calculated (Altabet and McCarthy, 1986) as:

$$
\text { Weighted } \delta^{15} \mathrm{~N}=\frac{\sum_{1}^{n}\left(P O N_{n} * \delta^{15} N_{n}\right)}{\sum_{1}^{n} P O N_{n}}
$$

Here ' $n$ ' represents different depths at a given sampling location.

In the present study, the whole cruise track has been subdivided into four Sections; Section 1 (north central Arabian Sea) includes Stations 1 and 2, Section 2 includes Oman shelf region (Stations 4, 6, 8-11, 1315), Section 3 includes Oman shelf to offshore Stations which retracting the southern line of the US JGOFS up to $15^{\circ} \mathrm{N}$ (Stations $16,18,20$ ), and the Section 4 includes Stations along the $15^{\circ} \mathrm{N}$ latitude, (south central Arabian Sea) (Stations 22, 24, 26, 28). The other intermediate Stations marked by stars were not sampled for $\delta^{15} \mathrm{~N}$. For the study period, surface wind data derived from the QuikSCAT scatterometer are available at http://apdrc.soest.hawaii.edu/dods/ public_data/satellite_product. Effect of upwelling observed using the sea surface height anomaly data are derived from the weekly merged data from multisatellite (TOPEX/Poseidon, ERS and Jason), which has a spatial resolution of $1 / 3$ degree. Level 3 weekly grided $\left(0.5^{\circ} \times 0.5^{\circ}\right)$

\section{Results}

\section{Hydrographic Condition}

Upwelling at the Omani coast is evidenced by the lower sea surface temperature $\left(\sim 22^{\circ} \mathrm{C}\right.$; SST). Upwelling in the western Arabian Sea is driven by strong southwesterly winds and is very vigorous. During end of the monsoon season also winds were southwesterly in the region (Fig. 2). Consequently low SST and higher nitrate signatures observed up to a distance of $\sim 1000 \mathrm{~km}$ from the Omani coast (Naqvi et al., 2010). SST increased from $\sim 22^{\circ} \mathrm{C}$ at the Oman coast in the western Arabian Sea to $\sim 28^{\circ} \mathrm{C}$ at the central and eastern Arabian Sea. Following winds, the upwelled water moves towards central Arabian
Sea as evident by the higher sea surface height anomaly (Fig. 2). Upwelling also occurs at the west coast of India as evidenced by the lower SST $\left(\sim 23^{\circ} \mathrm{C}\right)$ but its effect remains limited to the coastal region (Naqvi et al., 2010). Upwelling in the eastern Arabian Sea is remotely forced, and much less energetic (McCreary et al., 1993). Nitrate pattern shows an opposite trend from SST, nitrateis maximum $(\sim 10 \mu \mathrm{M})$ at the Oman coast and gradually decreases to near detection limit in the central Arabian Sea (Naqvi et al., 2010). There is a large variation $(<8 \mu \mathrm{M}$ to $>16 \mu \mathrm{M})$ in the surface nitrate within the Omani coast, with the higher values in the south-eastern part, where high nitrate-low chlorophyll (HNLC) conditions develop due to Fe limitation (Naqvi et al., 2010), causing under-utilization of nitrate. Surface chlorophyll is higher at Station 7 (> $5 \mathrm{mg} \mathrm{m}^{-3}$; situated in the north-eastern part of the Omani coast) than that at Station $16\left(<0.1 \mathrm{mg} \mathrm{m}^{-3}\right.$; situated in the south-eastern part of the Omani coast). Fe limitation in the southeastern part promotes under-utilization of nitrate. As the upwelled water in the western Arabian Sea spreads eastward, it retains its high nitrate content far away from its origin $(\sim 1000 \mathrm{~km})$. Diatoms dominate the plankton community along the western Arabian Sea (Brown et al., 2002), whereas plankton community shifts towards smaller autotrophic types due to the depletion of silicate offshore during this season (Garrison et al., 1998).

\section{Nitrogen Isotopic Composition of PON}

\section{Central Arabian Sea}

Surface values of PON and its $\delta^{15} \mathrm{~N}$ along with the Station locations are given in Table 1. Section 1 includes Stations 1 and 2. Although both the Stations lie in the central Arabian Sea a large difference is found in the surface values of PON: 1.9 and $5.8 \mu \mathrm{M}$ at Stations1 and 2, respectively. Such a difference is observed in surface $\delta^{15} \mathrm{~N}$ values as well, 12.3 and $6.6 \%$ at Stations 1 and 2, respectively (Table 1). Station 1 lies within the area influenced by the upwelled water at the Omani coast but not Station 2. This is could be the reason for the large difference in PON and its $\delta^{15} \mathrm{~N}$ values at both the locations. PON weighted $\delta^{15} \mathrm{~N}$ values for different depth intervals are shown in Fig. 3a. PON weighted $\delta^{15} \mathrm{~N}$ is generally higher at Station 1 than at Station 2, except at the 500-2500 depth interval (Fig 3a). A progressive 

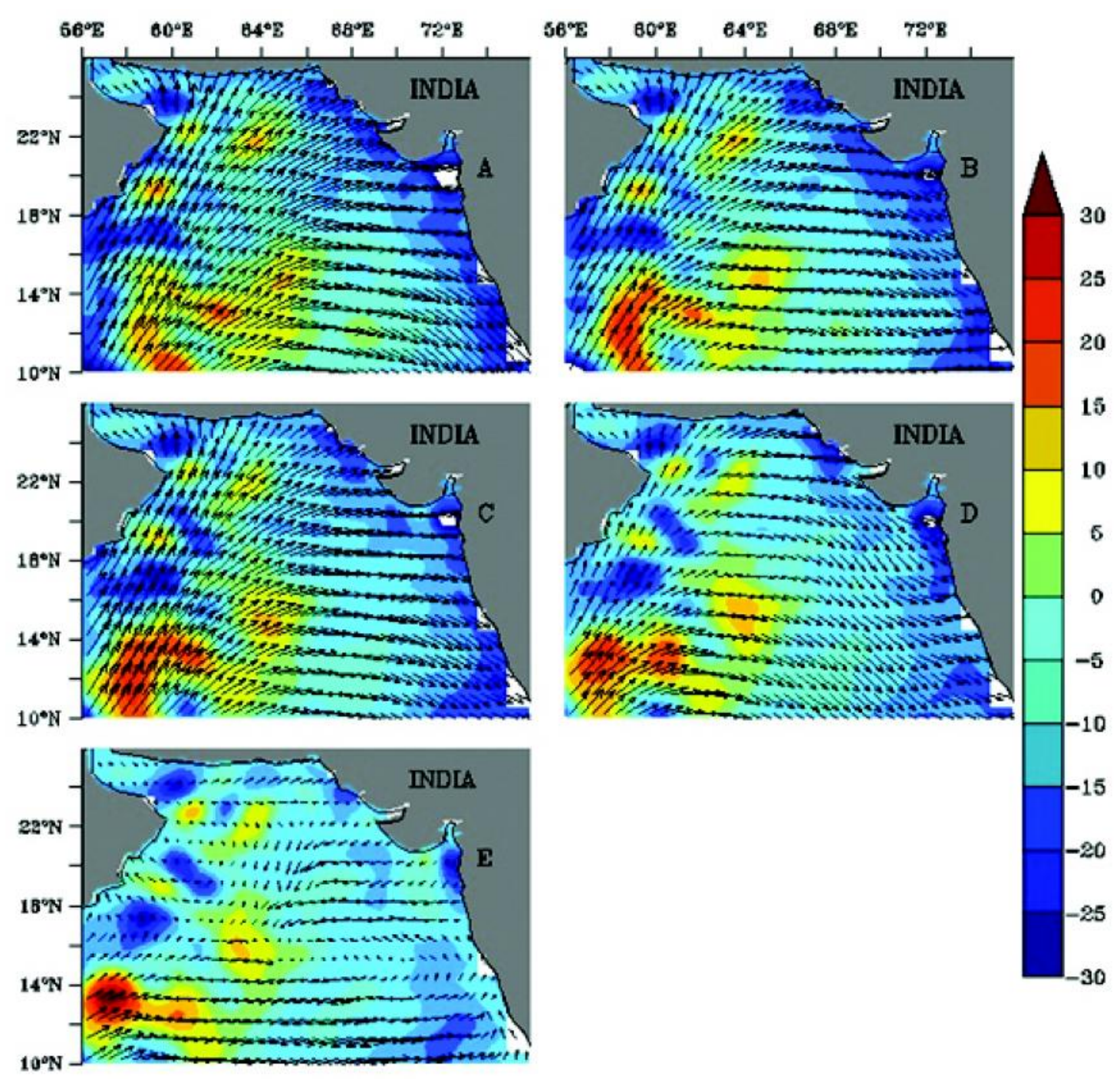

Fig. 2: Sea Surface height anomaly (legend on the right, in $\mathrm{cm}$ ) images overlaid with surface winds (source: http:// apdrc.soest.hawaii.edu/dods/public_data/satellite_product) showing different periods (A) 29 August-04 September, (B) 05-11 September, (C) 12-18 September, (D) 19-25 September, (E) 26 September-02 October 2004 in the Arabian Sea.

increase in PON weighted $\delta^{15} \mathrm{~N}$ from 10.2 to $16.1 \%$ o was observed up to $250 \mathrm{~m}$ at Station 2, whereas, at Station 1 a sudden increase (from 14.8 to $27.6 \%$ ) was found at $50-100 \mathrm{~m}$ from $0-50 \mathrm{~m}$. PON weighted $\delta^{15} \mathrm{~N}$ decreased after $500 \mathrm{~m}$ at Station 1, whereas, it increased after $500 \mathrm{~m}$ at Station 2 (Fig. 3a). No clear trend has been observed in PON weighted $\delta^{15} \mathrm{~N}$ at both these Stations.

\section{Oman Shelf Region}

This Section includes Stations from the Oman shelf region. PON varied from 3.9 to $13.2 \mu \mathrm{M}$ (with an average of $7.5 \mu \mathrm{M})$. PON was relatively very high (more than $12 \mu \mathrm{M}$ ) at two Stations (6 and 15) (Table
1). The average PON in the shelf region became 5.9 $\mu \mathrm{M}$ by excluding both the Stations. $\delta^{15} \mathrm{~N}$ values in the surface varied from 8.2 to $12.8 \%$ (with an average $10.8 \%$ ), excluding Station 4 at which $\delta^{15} \mathrm{~N}$ was $1.8 \%$ 。 (Table 1). The average value decreased to $9.8 \%$ o by including Station 4. PON weighted $\delta^{15} \mathrm{~N}$ up to $50 \mathrm{~m}$ and below $50 \mathrm{~m}$ values for the representative Stations $(4,6,8,11$ and 14) which cover the whole region across the coast are plotted in Fig. 3b. PON weighted $\delta^{15} \mathrm{~N}$ for upper $50 \mathrm{~m}$ values were lower than that of below $50 \mathrm{~m}$ at all the Stations. PON weighted $\delta^{15} \mathrm{~N}$ for upper $50 \mathrm{~m}$ ranged from 6.0 to $11.8 \%$ o, whereas it varied from 8.6 to $28.8 \%$ o below $50 \mathrm{~m}$. PON weighted $\delta^{15} \mathrm{~N}$ values in the upper $50 \mathrm{~m}$ are comparable at all 
Table 1. Station number, sampling position, surface particulate organic nitrogen (PON) and its $\delta^{15} \mathrm{~N}$ data at different Stations

\begin{tabular}{|c|c|c|c|c|}
\hline $\begin{array}{l}\text { Station } \\
\text { No. }\end{array}$ & $\begin{array}{l}\text { Latitude } \\
\qquad\left({ }^{\circ} \mathrm{N}\right)\end{array}$ & $\begin{array}{l}\text { Longitude } \\
\left({ }^{\circ} \mathrm{E}\right)\end{array}$ & $\begin{array}{l}\text { PON } \\
(\mu \mathrm{M})\end{array}$ & $\delta^{15} \mathrm{~N}(\% o)$ \\
\hline \multicolumn{5}{|c|}{ Section 1} \\
\hline 1 & 68.0 & 17.0 & 1.9 & 12.3 \\
\hline 2 & 64.6 & 19.8 & 5.8 & 6.6 \\
\hline \multicolumn{5}{|c|}{ Section 2} \\
\hline 4 & 58.6 & 23.5 & 3.9 & 1.8 \\
\hline 6 & 59.6 & 22.6 & 13.2 & 11.1 \\
\hline 8 & 59.6 & 21.6 & 8.1 & 12.3 \\
\hline 9 & 59.0 & 21.1 & 6.4 & 12.8 \\
\hline 10 & 59.3 & 20.8 & 6.4 & 8.2 \\
\hline 11 & 58.8 & 20.4 & 5.2 & 11.3 \\
\hline 13 & 57.9 & 18.8 & 4.8 & 9.6 \\
\hline 14 & 57.1 & 18.6 & 6.8 & 11.5 \\
\hline 15 & 57.3 & 18.5 & 12.6 & 9.6 \\
\hline \multicolumn{5}{|c|}{ Section 3} \\
\hline 16 & 57.6 & 18.2 & 3.1 & 13.0 \\
\hline 18 & 58.8 & 17.7 & 7.4 & 8.2 \\
\hline 20 & 61.2 & 16.4 & 6.1 & 6.0 \\
\hline \multicolumn{5}{|c|}{ Section 4} \\
\hline 22 & 64.0 & 15.0 & 4.3 & 8.7 \\
\hline 24 & 66.0 & 15.0 & 3.5 & 11.3 \\
\hline 26 & 68.0 & 15.0 & 1.8 & 23.1 \\
\hline 28 & 70.0 & 15.0 & 2.0 & 25.4 \\
\hline
\end{tabular}

the locations, except at the northern most location (Station 4). Station 4 also shows the lowest value for 50-100 m depth interval.

\section{Oman Coast to South Central Arabian Sea}

Here surface PON and $\delta^{15} \mathrm{~N}$ of PON ranged from 3.1 to $7.4 \mu \mathrm{M}$ (with an average of $5.5 \mu \mathrm{M}$ ) and 6.0 to $13.0 \%$ (with an average of $9.1 \%$ ), respectively (Table 1). A general decreasing trend was observed in the surface $\delta^{15} \mathrm{~N}$ from the Oman coast to off-shore, whilst the trend reversed for surface PON. PON weighted $\delta^{15} \mathrm{~N}$ for upper 50m decreased from the Omani coast to offshore range from 9.6 to $14.7 \%$, whereas, it remained comparable for $50-100 \mathrm{~m}$ depth interval at all the locations (Fig. 3c).

\section{South Central Arabian Sea}

This Section includes Stations along the $15^{\circ} \mathrm{N}$ transect.
Surface PON ranged from 1.8 to $4.3 \mu \mathrm{M}$ (with an average of $2.9 \mu \mathrm{M}$ ) and $\delta^{15} \mathrm{~N}$ of surface PON varied from 8.7 to $25.4 \%$ o (with an average of $17.1 \%$ o) for this Section (Table 1). Generally, surface PON decreased from the west to the east, whereas $\delta^{15} \mathrm{~N}$ of surface PON increased (Table 1). There was a progressive increase observed in PON weighted $\delta^{15} \mathrm{~N}$ for upper $50 \mathrm{~m}$ from the west to the east (Fig. 3d). Overall, PON weighted $\delta^{15} \mathrm{~N}$ for upper $50 \mathrm{~m}$ varied from 10.0 to $24.2 \%$, whereas it varied from 22.7 to $32.0 \%$ or for $50-100 \mathrm{~m}$. Generally, PON weighted $\delta^{15} \mathrm{~N}$ for upper $50 \mathrm{~m}$ was lower than that for $50-100 \mathrm{~m}$ depth, except at Station 26 (Fig. 3d).

\section{Longitudinal Variation}

Figure 4 shows the longitudinal variation of the surface PON and $\delta^{15} \mathrm{~N}$ of PON. An opposite trend has been observed for PON and its nitrogen isotopic composition from the east to the west. The highest PON value is found near the Oman coast whereas the lowest value is observed near to the west coast of India. In contrast, the latter region has the highest $\delta^{15} \mathrm{~N}$ of PON and the lowest is found in the former. The region near to the Oman coast $\left(56^{\circ} \mathrm{E}\right.$ to $\left.60^{\circ} \mathrm{E}\right)$ shows a large variation in the PON, varied from 3.1 to $13.2 \mu \mathrm{M}$, whereas spread is comparatively less in the $\delta^{15} \mathrm{~N}$ of PON, it varies from 8.2 to $13.0 \%$ o (barring Station 4).

\section{Discussion}

\section{Vertical Patterns}

A large variation in the PON and $\delta^{15} \mathrm{~N}$ of PON has been found in the in the central AS (Station 1 and 2) which indicates that several processes are acting together in the region. Station 2 is certainly influenced by upwelling at the Omani coast. The upwelling supplies sub-surface nitrate to the surface and this water mass advects towards central Arabian Sea. Such a supply of water mass of lower $\delta^{15} \mathrm{~N}_{\text {. and/or }}$ nitrate of lower $\delta^{15} \mathrm{~N}$. imparts its effect throughout the water column in the central Arabian Seaas seen in the observed $\delta^{15} \mathrm{~N}$ values. No regular pattern has been seen in the $\delta^{15} \mathrm{~N}$ values from surface towards the deep at Station 2. Lower values of $\delta^{15} \mathrm{~N}$ are observed in deeper samples too. Remineralization and mixing of laterally advected water mass decides the overall variation of $\delta^{15} \mathrm{~N}$ at this location. In contrast, Station 1 lies within the area of intense denitrification 

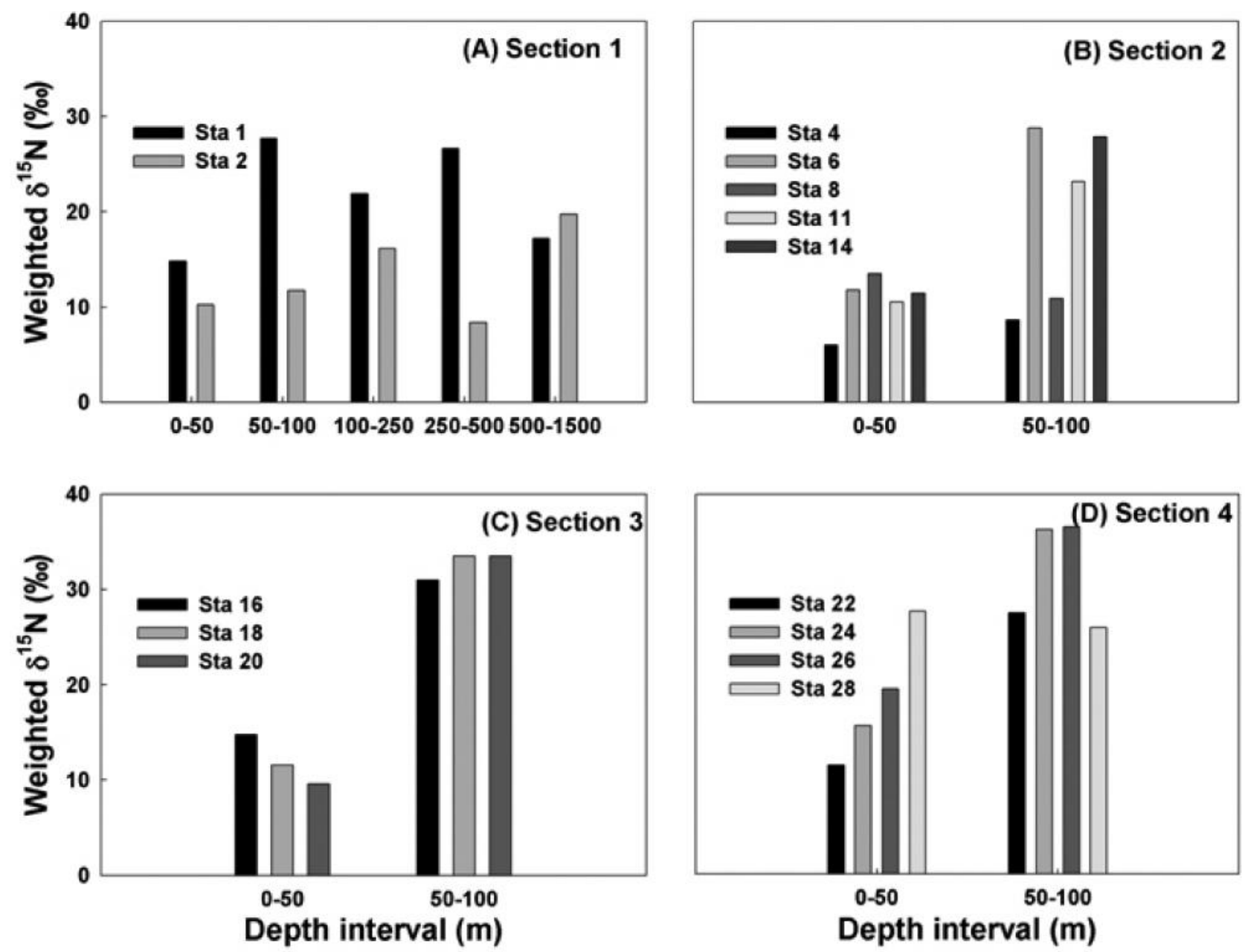

Fig. 3: Variation of PON-weighted $\delta^{15} \mathrm{~N}$ with depth. Different plots (a-d) correspond to representative Stations from different Sections (1-4). Legends show Station number

and out of the influence of upwelling water mass of the Omani coast (Naqvi, 1991). At Station 1, a steady increase in the PON weighted $\delta^{15} \mathrm{~N}$ from surface-50 $\mathrm{m}$ to 100-200 $\mathrm{m}$ suggests the progressive remineralization of organic matter. A large variation of PON weighted $\delta^{15} \mathrm{~N}$ for different depths between Station 1 and 2 could be because of the variability in the vertical scale of mineralization in the different parts of the Arabian Sea (Naqvi et al., 2010).

In most of the locations, value of weighed $\delta^{15} \mathrm{~N}$ below $50 \mathrm{~m}$ is more than that of upper $50 \mathrm{~m}$ (Fig. 3). Though higher values of $\delta^{15} \mathrm{~N}$ are associated with lower PON values there is no strong linear relationship which suggests the involvement of other processes in governing the $\delta^{15} \mathrm{~N}$ of PON. Further, no gradient has been observed in the surface $\delta^{15} \mathrm{~N}$. values from shelf region towards off-shore. However, weighted values of $\delta^{15} \mathrm{~N}$ for upper $50 \mathrm{~m}$ show a steady increase from open to coastal locations (Fig. 3), whereas such effects diminishes below $50 \mathrm{~m}$ due to the remineralization and mixing. In general, in most of the Stations, weighed $\delta^{15} \mathrm{~N}$ below $50 \mathrm{~m}$ is more than that of upper $50 \mathrm{~m}$, except at the Station 28 (close to the coast and could have terrestrial inputs).

Two parameters viz., $\Delta \delta^{15} \mathrm{~N}$ and ' $F$ ' have been used Altabet and McCarthy (1986) to point out the role of different processes occurring in the warmcore eddies and the Sargaso Sea on the PON and its $\delta^{15} \mathrm{~N}$.

Here, $\Delta \delta^{15} \mathrm{~N}$ is the difference between the maximum $\delta^{15} \mathrm{~N}$ value and $\delta^{15} \mathrm{~N}$ value associated with the maximum PON and $F=\left(1-\left(\mathrm{PON}\right.\right.$ at $\max \delta{ }^{15} \mathrm{~N} /$ PONmax)). 


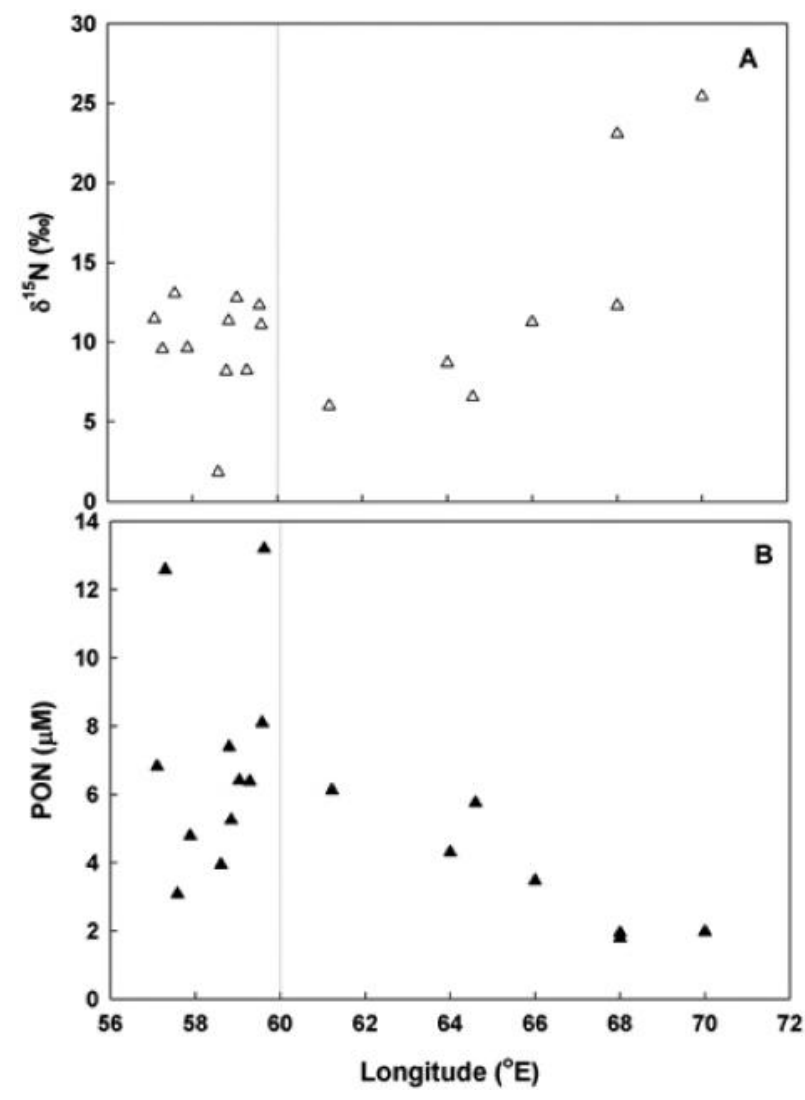

Fig. 4: Longitudinal variation of surface PON (lower panel) and $\delta^{15} \mathrm{~N}$ of surface PON (upper panel). Vertical gray line separates sampling locations near the Oman coast (left of the line) from the rest (right of the line)

$F$ indicates the degree of degradation of organic matter. If degradation were the only process controlling PON, there should be a relationship between $F$ and the observed increase in $\delta^{15} \mathrm{~N}$. A plot between In $F$ and $\Delta \delta^{15} \mathrm{~N}$ provides of theinformation about the effect of degradation over observed $\delta^{15} \mathrm{~N}$. Any scatter in the plot hints towards the involvement of other processes controlling the variation in $\delta^{15} \mathrm{~N}$ of PON. Fig. 5 presents a plot of $\ln F$ vs. $\Delta \delta^{15}$ N. There is a trend toward a greater range in $\Delta \delta^{15} \mathrm{~N}$. with decreasing $\ln F$ suggesting that the lower amount of remineralization can result in larger $\delta^{15} \mathrm{~N}$. values (Fig. 5). However, large degree of scatter and lack of a linear relationship indicate that the assumption that degradation is the only process controlling PONand its $\delta^{15} \mathrm{~N}$ is too simplistic. The plot indicates that processes in addition to particle decomposition control the concentration of PON and its $\delta^{15} \mathrm{~N}$. Wind driven mixing andadvectedflow from the West are the plausible factors for the deviation froma linear relationship between $\ln F$ and $\Delta \delta^{15} \mathrm{~N}$.

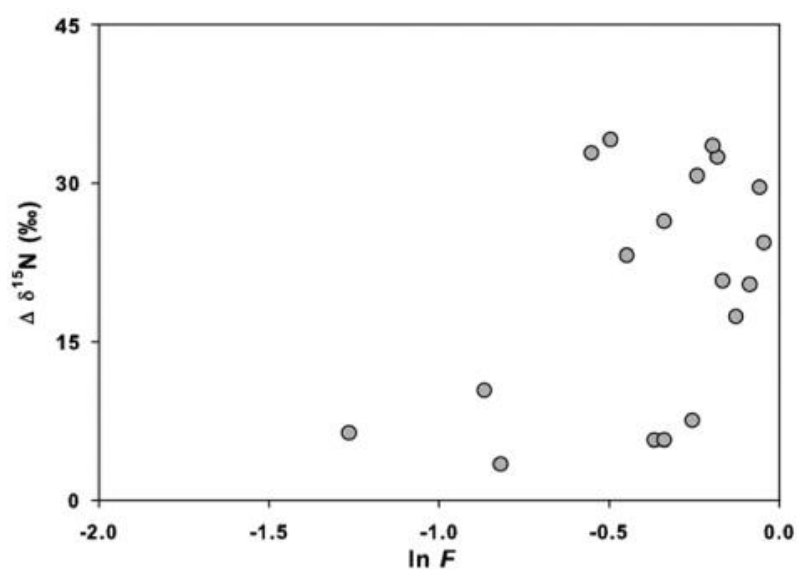

Fig. 5: Variation of $\Delta \delta^{15} \mathrm{~N}$ with $\ln \mathrm{F}$ for all the sampling locations. $\Delta \delta^{15} \mathrm{~N}$. is the difference between the maximum $\delta^{15} \mathrm{~N}$ value and $\delta^{15} \mathrm{~N}$ value associated with the maximum PON and $F=\left(1-\left(P O N\right.\right.$ at $\max \delta^{15} \mathrm{~N} /$ PONmax))

\section{Spatial Variation}

Measurements of $\delta^{15} \mathrm{~N}$ of surface PON in the Arabian Sea suggest that advection plays a critical role in the $\delta^{15} \mathrm{~N}$ of PON values in the off-shore Oman and the central AS during late SW monsoon. Relatively low scatter in the $\delta^{15} \mathrm{~N}$ values (Fig. 4) near the Oman coast suggests a supply of nitrate of similar isotopic composition from below which supports the plankton bloom in the region. As the unutilized, ${ }^{15} \mathrm{~N}$ enriched nitrate moves towards the central AS due to the wind forcing, it shows a progressive enrichment in the $\delta^{15} \mathrm{~N}$ of surface PON (Fig. 4). Similarly, PON values show a progressive decline from the Omani coast to offshore (Fig. 4) suggests a progressive depletion of nutrients towards central AS. However, a large scatter in the PON values near to the coast of Oman has been found. Similarly, a large scatter is also observed in the surface chlorophyll $a$ values (Naqvi et al., 2010). This could be due to the varying supply and/or underutilization of nutrient or patchiness of plankton. As said earlier, Fe limitation could be a plausible reason for the under-utilization of nitrate in the south-eastern part of the Omani coast which results in the large scatter in the PON and chlorophyll $a$ values. The effect of Fe limitation diminishes in the offshore region by the supply of Fe through atmospheric deposition (Naqvi et al., 2010). Therefore, the unutilized nitrate moves toward offshore region and is being utilized while progressing eastward. The $\delta^{15} \mathrm{~N}$ of the remaining nitrate pool is enriched by this utilization and so is its $\delta^{15} \mathrm{~N}$ in the eastward direction. 


\section{Conclusions}

No clear linear trend exists between PON and its $\delta^{15} \mathrm{~N}$ as the combined effects of remineralization, supply of nitrate, and/or PON of lower $\delta^{15} \mathrm{~N}$ from the Oman coast through advection mainly govern these parameters. Mixing by winds further modified the $\delta^{15} \mathrm{~N}$ of PON in the surface. Our observations suggest that the mixing and advection dominates the remineralization effect during the season particularly in upper $50 \mathrm{~m}$. Though remineralization overcomes the other effects and causes enrichment in the $\delta^{15} \mathrm{~N}$ in the deeper samples, yet at some locations, lateral advection imprints its signature in the deeper water

\section{References}

Altabet M A (1988) Variations in nitrogen isotopic composition between sinking and suspended particles: implications for nitrogen cycling andparticle transformation in the open ocean Deep-Sea Research 35 535-554

Altabet M A and Francois R (1994) The use of nitrogen isotopic ratio for reconstruction of past changes in surface ocean nutrient utilization, in Carbon Cycling in the Glacial Ocean: Constraints on the Ocean's Role in Global Change NATO ASI Series 17 edited by R Zahn et al., pp. 281-306, SpringerVerlag, New York

Altabet M A and MacCarthy J J (1985) Temporal and spatial variations in the natural abundance of $15_{\mathrm{N}}$ in PON from a warm-core ring Deep Sea Research 32 755-772

Altabet M A and MacCarthy J J (1986) Vertical patterns in ${ }^{15} \mathrm{~N}$ natural abundance in PON from the surface waters of warmcore rings Journal of Marine Research 44 185-201

Bange H W, Naqvi S W A and Codispoti LA (2005) The nitrogen cycle in the Arabian Sea Progress in Oceanography 65 $145-158$

Barber R T, Marra J, Bidigare R C, Codispoti L A, Halpern D, Johnson Z, Latasa M, Goericke R and Smith S L (2001) Primary productivity and its regulation in the Arabia Sea during 1995 Deep-Sea Research II 48 1127-1172

Brown S L, Landry M R, Christensen S, Garrison D, Gowing M M, Bidigare R R and Campbell L (2002) Microbial community dynamics and taxon-specific phytoplankton production in the Arabian Sea during the 1995 monsoon seasons Deep-Sea Research II 49 2345-2376

Devassy V P, Bhattathiri P M A and Qasim S Z (1978) Trichodesmium Phenomenon Indian Journalof Marine Science 7 168-186 too e.g. Station 2. A linear trend has been found in the surface PON and its $\delta^{15} \mathrm{~N}$ from the Oman coast to the central AS. This trend supports the inference that the unutilized upwelled nitrate in the Oman coast advects towards central AS by winds and imparts its signature in the $\delta^{15} \mathrm{~N}$ of PON.

\section{Acknowledgments}

We thank Dr. S Sardesai and crew of the ORV Sagar Kanya (SK-209) for collecting the samples; ISROGBP Department of Space, Government of India for financial support.

Emerson S P, Quay P, Stump C, Wilbur S and Knox M (1991) O, $\mathrm{Ar}, \mathrm{N}_{2}$ and ${ }^{222} \mathrm{Rn}$ in surface waters of subarctic ocean: net biological $\mathrm{O} 2$ production Global Biogeochemical Cycles $\mathbf{5}$ 49-69

Gandhi N, Ramesh R, Srivastava R, Sheshshayee M S, Dwivedi R M and Raman M (2010) Nitrogen uptake rates in the presence of Trichodesmium in the north-eastern Arabian Sea during spring 2006 International Journal of Oceanography 2010 ID 127493, doi:10.1155/2010/127493

Gandhi N, Singh A, Prakash S, Ramesh R, Raman M, Sheshshayee M S and Shetye S (2011a) First direct measurements of $\mathrm{N}_{2}$ fixation during Trichodesmium bloom in the eastern Arabian Sea Global Biogeochemical Cycles 25 GB4014, doi: 10.1029/2010GB003970

Gandhi N, Ramesh R, Prakash S and Kumar S (2011b) Nitrogen sources for new production in the NE Arabian Sea Journal of Sea Research $\mathbf{6 5}$ 265-274

Garrison D L, Gowing M M and Hughes M P (1998) Nano- and microplankton in the northern Arabian Sea during the southwest monsoon, August-September 1995: A USJGOFS study Deep-Sea Research II 45 2269-2299

Madhupratap M S, Prasanna Kumar S, Bhattathiri P M A et al. (1996) Mechanism of the biological response to winter cooling in the northeastern Arabian Sea Nature 384 549552

McCreary J P, Kundu P K and Molinari R L (1993) A numerical investigations of dynamics, thermodynamics and mixed layer processes in the Indian Ocean Progress in Oceanography 31 181-244

Montoya J Pin Nitrogen in the Marine Environment, ed. 2, D.G. Capone, E.J. Carpenter, M R Mulholland, D A Bronk Eds. (Academic Press, Burlington, MA, 2008), pp. 1277- 
1302

Montoya J P and McCarthy J J (1995) Nitrogen isotope fractionation during nitrate uptake by marine phytoplankton in continuous culture Journal of Plankton Research 17 439-464

Naqvi S W A (1987) Some aspects of the oxygen-deficiency conditions and denitrification in the Arabian Sea Journal of Marine Research 49 1049-1072

Naqvi S W A(1991) Geographical extent of denitrification in the Arabian Sea in relation to some physical processes Oceanologica Acta 14 281-290

Naqvi S W A, Moffett J W, Gauns M U, Narvekar P V, Pratihary A K, Naik H, Shenoy D M, Jayakumar D A, Goepfert T
J, Patra P K, Al-Azri A and Ahmed S I (2010) The Arabian Sea as a high-nutrient, low-chlorophyll region during the late Southwest Monsoon Biogeosciences 7 2091-2100 doi: 10.5194/bg-7-2091-2010

Nicholls J C, Davies C A and Trimmer M (2007) High resolution profiles and nitrogen isotope tracing reveal a dominant source of nitrous oxide and multiple pathways of nitrogen gas formation in the central Arabian Sea Limnology and Oceanography 52 156-168

Owens N J P and Rees A P (1989) Determination of nitrogen-15 at sub-microgram levels of nitrogen using automated continuous-flow isotope ratio mass spectrometer Analyst 114 1655-1657. 